Mesopotamia Journal of Agriculture

$\underline{\text { https://magrj.mosuljournals.com }}$

\title{
EFFECT OF SALICYLIC ACID APPLICATION ON GROWTH AND DEVELOPMENT OF GREEN ONIONS GROWN UNDER SALT STRESS
}

Noura M. Kka

Department of Horticulture, College of Agricultural Engineering Sciences, Salahaddin University-Erbil, Kurdistan Region, Iraq

\begin{tabular}{l} 
Article information \\
Article history: \\
Received:27/6/2021 \\
Accepted: $12 / 8 / 2021$ \\
Available: $12 / 9 / 2021$ \\
\hline
\end{tabular}

Keywords:

Salt stress,

Salicylic acid

green onion.

DOI:

$\underline{10.33899 / \text { magri.2021.130333.1133 }}$

Correspondence

Email: noura.kka@su.edu.krd

\section{ABSTRACT}

Soil salinity negatively affects crop production and leads to loss of agricultural lands worldwide. In Iraq, poor agricultural practices, such as inadequate drainage facilities and low water quality, are known to be caused soil salinization. Onion (Allium cepa L.) is an economic crop that is consumed heavily as green or dry bulb onion. The cultivated area of green onion was statistically decreased in the Kurdistan region, Iraq, lately. Therefore, this study was conducted in the Directorate of Agriculture, Ankawa, Erbil, to examine whether salicylic acid (SA) mitigate the effect of salt stress and improve the growth and development of green onions. Two different concentrations of $\mathrm{NaCl}$ (20 and $40 \mathrm{mM}$ ) were injected around the base of each plant and after $24 \mathrm{~h}, \mathrm{SA}(0.5$ and $1 \mathrm{mM})$ was sprayed to the vegetative parts of each plant, evenly. The results showed that the short-term application of SA was reduced the impact of $\mathrm{NaCl}$. The number of green leaves, leaf area, plant height, root growth, bulb diameter, plant weight and total yield (t. ha-1) was improved by the application of SA. It has been suggested the application of a commercial or SA analogue to the agricultural saline land may alleviate the salt stress and improve the product.

College of Agriculture and Forestry, University of Mosul.

This is an open access article under the CC BY 4.0 license (https://magrj.mosuljournals.com/ ).

\section{INTRODUCTION}

High salinity stress continues to threat crop production and loss of agricultural land. A case study in Iraq was shown that saline soil increases from north to south and the highest percentage of dissolved salt was found in the irrigated water from Tigris and Euphrates rivers (Jawad, 2020). Salt stress modifies plant physiological and biochemical systems, and results in reduction of plant growth and development (Kamran et al., 2020). Onion (Allium cepa L.) is an economic crop that is consumed heavily as green or dry bulb onion. The cultivated area of green onion was decreased almost 2\% in 2019 in comparison to the previous year in northern Iraq (Anonymous, 2019). Onion species response differently to salt stress according to the recent publication by Plabon (2021). Cell division rate in roots of onion plants was reduced by high salt concentrations, hence the plant growth and productivity was reduced significantly (Singh and Roy, 2016). However, to mitigate the impact of salt stress on plant growth and development, different strategies have been used including intercropping with halophyte species (Lastiri-Hernández, 2021), 
antioxidant compound (Mohamed and Aly, 2008) and plant growth regulator and widely applied salicylic acid (SA) (Ashraf et al., 2010 and da Silva et al., 2019). $\mathrm{SA}$ is known to reduce biotic and abiotic stress in plants by activation of the defense system (Wani et al., 2017). In addition, SA is commonly known as a plant growth regulator, which enhances plant growth and development.

SA application has been used to reduce abiotic stress in plants, however, the plant response to SA application depends on the species, variety and growth stage (Mohammadi et al., 2019; da Silva et al., 2019 and Wijoyo et al., 2019). In plants, SA is biosynthesized through two different pathways: isochorismate (ICS) and phenylalanine ammonia-lyase (PAL) pathways, and its level varies within different plant organs, it has shown that its level is higher in shoot in compression to the roots in rice (Duan et al., 2014 and Lefevere et al., 2020). The foliar application of $250 \mathrm{ppm}$ of SA at different growing stages, significantly was increased vegetative growth and onions bulbs parameters when compared to the control treatment (Pradhan et al., 2016).

It is difficult to maintain the supply vegetables to meet the demands of the market, and is expected to continue increasing over the next decade, due to the conversion of agricultural lands to residential purposes, drought and salinity specifically, in the Kurdistan Region, Iraq. Salt concentration in the soil was found to be increased due to poor management and growth conditions (Singh, 2019). Therefore, this study aimed to examine the impact of SA spraying after $24 \mathrm{~h}$ of salt $(\mathrm{NaCl})$ application on the morphology, phenotype and yield of green onion.

\section{MATERIALS AND METHODS}

\section{Experimental site and treatments}

A field experiment was carried out at the research center farm of the Directorate of Agriculture, Ankawa, Erbil, Kurdistan Region, Iraq $\left(36.1^{\circ} \mathrm{N}, 4^{\circ} \mathrm{E}\right.$ and 434 Meters above mean sea level) during the growing season (OctoberJanuary) (2020-2021). The experimental soil was silty clay in texture, (sand, silt, clay, 90, 569, $341 \mathrm{Kg}$, respectively), its $\mathrm{pH}$ was 8.46 ; EC $0.72 \mathrm{dS} \mathrm{m}^{-1}$; organic matter $105 \mathrm{~g} . \mathrm{kg}^{-1}$; available $\mathrm{N}, \mathrm{P}, \mathrm{K} 4.6,3.6$ and $1.17 \mathrm{mg} . \mathrm{kg}^{-1}$, respectively. The average temperature and humidity range between $\left(5-28^{\circ} \mathrm{C}\right)$ and $(30-57 \%)$ respectively, during the growing season (Anonymous, 2021).

The field was initially ploughed and the organic manure was applied evenly $\left(100 \mathrm{gm} .1 \mathrm{~m}^{-2}\right)$, and this was followed by rotator for land leveling. A drip irrigation system was installed, the distance between the tape $40 \mathrm{~cm}$ and $10 \mathrm{~cm}$ between the plants. Onion (cv. Local red) seedlings of seven weeks old were obtained from ARD Kurdistan nursery and transplanted on October $5^{\text {th }}$ during 2020. Two weeks after transplanting, when seedlings were established 5-6 leaves and length between $30-40 \mathrm{~cm}$, irrigation was stopped until the surface of the soil dried. $10 \mathrm{~mL}$ of $\mathrm{NaCl}(0,20$ and $40 \mathrm{mM})$ was injected once using $10 \mathrm{~mL}$ syringes around the base of each plant. $24 \mathrm{~h}$ later SA $(0,0.5$ and $1 \mathrm{mM})$ was sprayed once evenly to each plant using two-liter sprayer. Irrigation was resume two days after SA treatment. Fertigation was applied according to recommended rate only for the first stage of the growth (Dingre et al., 2016). Weed and pest management was carried out as required. 


\section{Experimental design, data collection and analysis}

Factorial experiment using randomize complete block design was conducted with three replicates $(3 \times 3 \times 3)$. Ten plants for each experimental unit. A hundred days after transplanting (DAT), four randomly plants were chosen per experimental unit to recorded the data. The number of green leaves was counted from fully developed leaves and the average was computed for each plant. Leaf area $\left(\mathrm{cm}^{2}\right)$ was computed using a digital picture captured by a digital camera, then the leaf area was measured using Image J 1.52m software (Córcoles et al., 2015). Plant height $(\mathrm{cm})$ was measured from the ground level up to the tip of the longest leaf using measuring tape. Root length $(\mathrm{cm})$ was measured from the stem to the tip of the longest root using measuring tape. Bulb diameters $(\mathrm{mm})$ was measured at the widest circumstance of the bulb using a Vernier caliper. Average bulb weight per plant $\left(\mathrm{gm}\right.$. plant $\left.{ }^{-1}\right)$ was calculated as the fresh bulb weight after harvesting. The total yield $\left(\mathrm{t} . \mathrm{ha}^{-1}\right)$ was recorded for the total number of plants per experimental unit and then converted into tons per hectare. Data were analyzed using IBM ${ }^{@}$ SPSS ${ }^{@}$ statistics, version 25 . Duncan multiple range test was applied to compare between the mean treatments at 0.5 level of significance.

\section{RESULTS AND DISCUSSION}

Salinity is one of the abiotic stresses that threat the future of agricultural industry (Singh, 2019). Over years of research, different chemical compounds and methods of application have been used to reduce the impact of salt stress on agricultural product (Kamran et al., 2020; Silva et al., 2019; Singh and Roy, 2016 and Wani et al., 2017). Species, varieties, growth stage, and different organs of the plant response differently to salinity tolerance under various growth conditions (Kamran et al., 2020). It has been shown that onion is a salt sensitive crop, however, its effect differs at different growth stage (Sta-Baba et al., 2010). Multiple phytohormones are involved in abiotic stress resistance in plant, SA stimulate growth and dry matter of onion seedling under salt stress (da Silva et al., 2019). In the present study, green onion (cv. Local red) growth and development response positively to different concentration of SA under salt stress.

The number of leaves per plant statistically decreased by increasing the concentration of salt from $20 \mathrm{mM}$ to $40 \mathrm{mM}$ in comparison to the control treatment (Figure 1A). The highest number of leaves per plant was found when the onion plants were spray with $1 \mathrm{mM}$ SA (Figure 1B). In the similar way, the interaction effect shows that $\mathrm{SA}$ mitigate the effect of $\mathrm{NaCl}$ on the number of leaves of green onion plant, the highest value was recorded when $1 \mathrm{mM}$ and $0.5 \mathrm{mM}$ were applied in the control treatment and $20 \mathrm{mM} \mathrm{NaCl}$ respectively, and the lowest value was found when plants were treated with $40 \mathrm{mM} \mathrm{NaCl}$ in the control treatment (Table 1). The size of leaf area of green onion was reduced significantly with $\mathrm{NaCl}$ treatment (Figure $2 \mathrm{~A}$ ), $40 \mathrm{mM} \mathrm{NaCl}$ shows bigger size of leaf area and significantly different when compared with $20 \mathrm{mM} \mathrm{NaCl}$ and this is maybe the effect of the interaction in between $\mathrm{NaCl}$ and SA (Table 2). The main effect of SA shows the bigger leaf area at $1 \mathrm{mM}$ treatment and both SA treatments $(0.5$ and $1 \mathrm{mM})$ increased the leaf area of green onion significantly 
when compared with the control treatment (Figure 2 B). The interaction effect of $\mathrm{NaCl}$ and SA shows that leaf area was bigger when plants were treated with $40 \mathrm{mM}$ in comparison with $20 \mathrm{mM}$ under the effect of SA, the biggest and smallest leaf area was recorded at $1 \mathrm{mM} \mathrm{SA}$ and $40 \mathrm{mM} \mathrm{NaCl}$ treatment respectively (Table 2). The plant height, which was measured from the surface of soil to the tallest green leaf, was statistically decreased by increasing the concentration of $\mathrm{NaCl}$ treatment (Figure 3A). Contrary, the highest plant was recorded in $1 \mathrm{mM}$ SA treatment in comparison to $0.5 \mathrm{mM} \mathrm{SA}$ and control treatment (Figure $3 \mathrm{~B}$ ). The interaction effect of $\mathrm{NaCl}$ and $\mathrm{SA}$ treatment shows that $0.5 \mathrm{mM}$ and $1 \mathrm{Mm}$ SA significantly decreased the effect of $20 \mathrm{mM}$ and 40 $\mathrm{mM} \mathrm{NaCl}$ on plant height of green onion when compared to the control treatment (Table 3). These results suggest that SA may moderate the effect of salt concentration and improves the growth of leaves and cell elongation. This is in agreement with the study conducted by Sta-Baba et al. (2010) who demonstrated a decrease in the number of onion leaf and plant height with increasing $\mathrm{NaCl}$ concentration. SA application was found to have a significant effect on plant height and other growth parameters of onions (Pradhan et al., 2016). However, it was reported that SA alleviate germination and growth of onion seeds only under salt stress (da Silva et al., 2019). It may suggest that SA reduces the effect of salt stress and interplay with reactive oxygen species (Herrera-VãiSquez at al., 2015) and modulate the plant growth of onion at the vegetative stage.
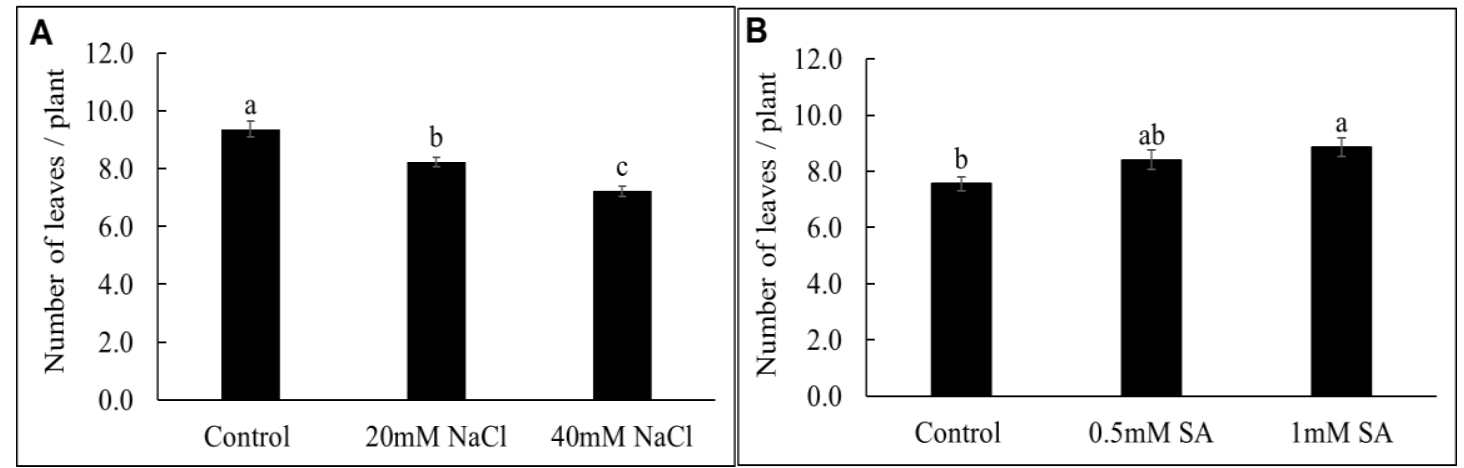

Figure (1): The number of green leaves per plant of green onion under the effect of $\mathrm{NaCl}$ and SA. (A) Main effect of $\mathrm{NaCl}$. (B) Main effect of SA on the number of green leaves of green onion at the age of 100 DAT. Values with different letters indicate significant difference at $\mathrm{P}<0.05$ according to Duncan multiple range test, $\mathrm{n}=3$, error bars represent $\pm \mathrm{SE}$.

Table (1): The interaction effect of $\mathrm{NaCl}$ and $\mathrm{SA}$ on the number of green leaves per plant of green onion at the age of 100 DAT.

\begin{tabular}{|c|c|c|c|}
\hline SA NaCl & Control & $20 \mathrm{mM} \mathrm{NaCl}$ & $40 \mathrm{mM} \mathrm{NaCl}$ \\
\hline Control & $8.333 \pm 0.08 \mathrm{~d}$ & $7.717 \pm 0.12 \mathrm{e}$ & $6.617 \pm 0.07 \mathrm{~g}$ \\
\hline $0.5 \mathrm{mM} \mathrm{SA}$ & $9.667 \pm 0.08 \mathrm{~b}$ & $8.300 \pm 0.12 \mathrm{~d}$ & $7.250 \pm 0.14 \mathrm{f}$ \\
\hline $1 \mathrm{mM} \mathrm{SA}$ & $10.073 \pm 0.21 \mathrm{a}$ & $8.683 \pm 0.04 \mathrm{c}$ & $7.817 \pm 0.04 \mathrm{e}$ \\
\hline
\end{tabular}

Values with different letters indicate significant difference at $\mathrm{P}<0.05$ according to Duncan multiple range test, $\mathrm{n}=3, \pm$ standard error (SE). 


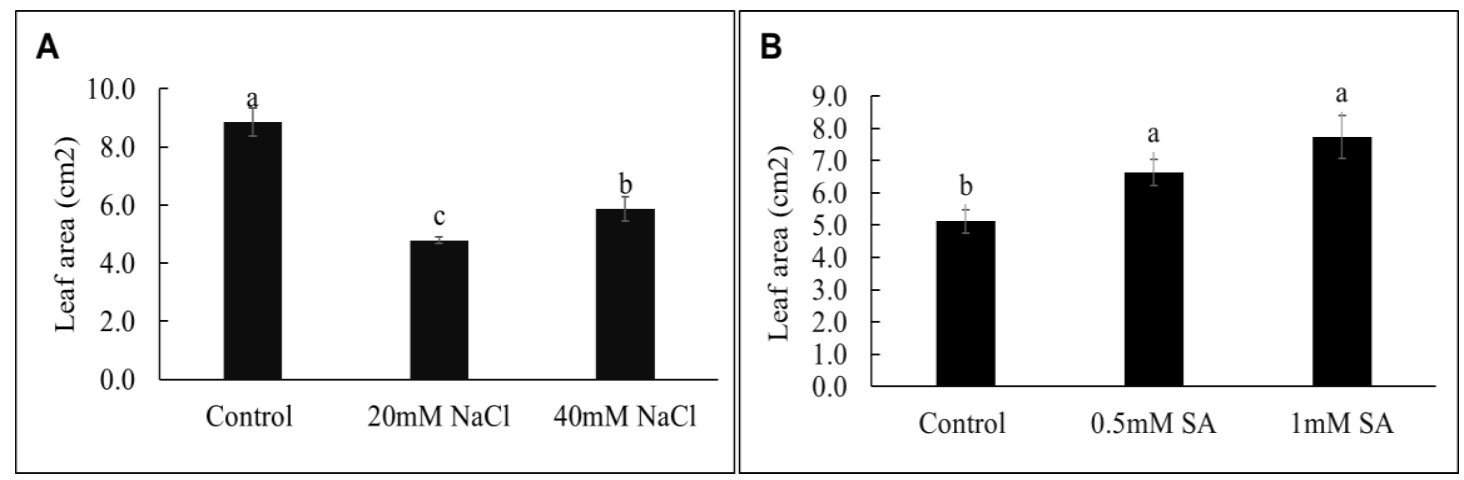

Figure (2): Leaf area of green onion under the effect of $\mathrm{NaCl}$ and SA. (A) Main effect of $\mathrm{NaCl}$. (B) Main effect of SA on leaf area of green onion at the age of 100 DAT. Values with different letters indicate significant difference at $\mathrm{P}<0.05$ according to Duncan multiple range test, $n=3$, error bars represent $\pm S E$.

Table (2): The interaction effect of $\mathrm{NaCl}$ and $\mathrm{SA}$ on leaf area $\left(\mathrm{cm}^{2}\right)$ of green onion at the age of 100 DAT.

\begin{tabular}{|c|c|c|c|}
\hline SA NaCl & Control & $20 \mathrm{mM} \mathrm{NaCl}$ & $40 \mathrm{mM} \mathrm{NaCl}$ \\
\hline Control & $6.786 \pm 0.38 \mathrm{c}$ & $4.862 \pm 0.64 \mathrm{~d}$ & $3.721 \pm 0.37 \mathrm{e}$ \\
\hline $0.5 \mathrm{mM} \mathrm{SA}$ & $8.412 \pm 0.17 \mathrm{~b}$ & $4.640 \pm 0.39 \mathrm{~d}$ & $6.849 \pm 0.35 \mathrm{c}$ \\
\hline $1 \mathrm{mM}$ SA & $11.341 \pm 0.23 \mathrm{a}$ & $4.866 \pm 0.44 \mathrm{~d}$ & $7.028 \pm 0.25 \mathrm{c}$ \\
\hline
\end{tabular}

Values with different letters indicate significant difference at $\mathrm{P}<0.05$ according to Duncan multiple range test, $\mathrm{n}=3, \pm$ standard error (SE).
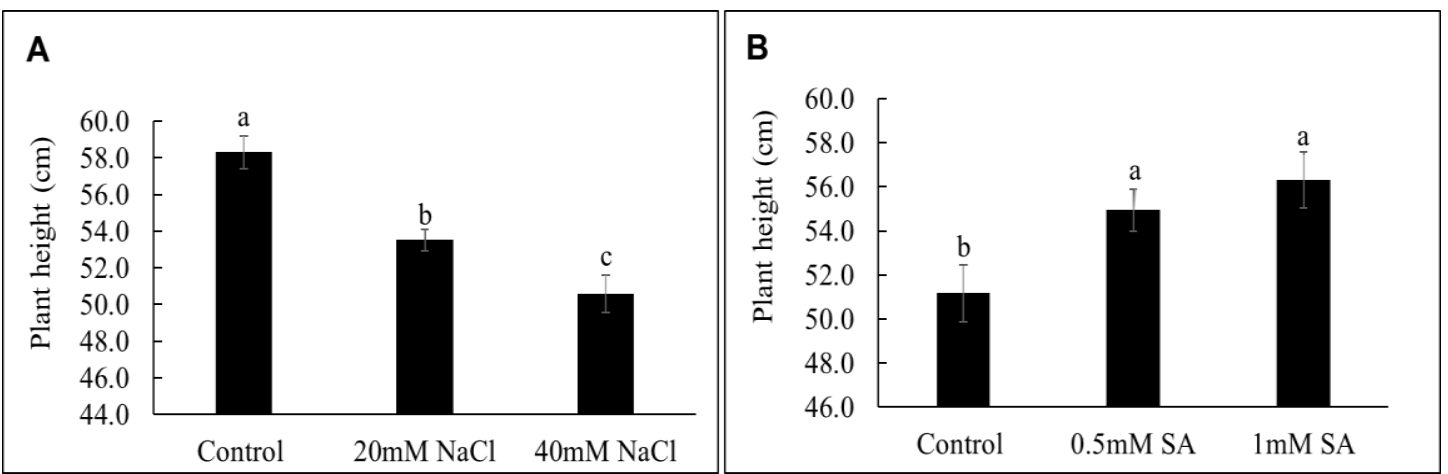

Figure (3): Plant height of green onion under the effect of $\mathrm{NaCl}$ and SA. (A)Main effect of $\mathrm{NaCl}$. (B) Main effect of SA on plant height $(\mathrm{cm})$ of green onion at the age of 100 DAT. Values with different letters indicate significant difference at $P$ $<0.05$ according to Duncan multiple range test, $n=3$, error bars represent \pm SE.

Table (3): The interaction effect of $\mathrm{NaCl}$ and $\mathrm{SA}$ on plant height $(\mathrm{cm})$ of green onion at the age of 100 DAT.

\begin{tabular}{|c|c|c|c|}
\hline $\mathrm{SA} N \mathrm{NaCl}$ & Control & $20 \mathrm{mM} \mathrm{NaCl}$ & $40 \mathrm{mM} \mathrm{NaCl}$ \\
\hline Control & $55.333 \pm 0.51 \mathrm{c}$ & $51.500 \pm 0.50 \mathrm{e}$ & $46.667 \pm 0.94 \mathrm{f}$ \\
\hline $0.5 \mathrm{mM} \mathrm{SA}$ & $58.500 \pm 0.52 \mathrm{~b}$ & $53.917 \pm 0.51 \mathrm{~cd}$ & $52.417 \pm 0.36 \mathrm{de}$ \\
\hline $1 \mathrm{mM} \mathrm{SA}$ & $61.083 \pm 0.65 \mathrm{a}$ & $55.167 \pm 0.22 \mathrm{c}$ & $52.667 \pm 0.58 \mathrm{de}$ \\
\hline
\end{tabular}

Values with different letters indicate significant difference at $\mathrm{P}<0.05$ according to Duncan multiple range test, $\mathrm{n}=3, \pm$ standard error (SE). 
Root growth, bulb size and yield of green onion were also affected by the short period of time of $\mathrm{NaCl}$ and $\mathrm{SA}$ treatment. Root length, bulb diameter, total weight per plant and yield (t.h $\left.\mathrm{h}^{-1}\right)$ were statistically and significantly decreased at 20 and $40 \mathrm{mM} \mathrm{NaCl}$ treatment when compared to the control treatment of green onion (Figure 4A, 5A, 6A and 7A). Oppositely, SA application significantly increased the values of the same parameters of green onion (Figure 4B, 5B, 6B and 7B). Onion root, bulb diameter and total weight response positively and similarly to 0.5 and $1 \mathrm{mM}$ SA treatment under different salt concentration $20 \mathrm{mM}$ and $40 \mathrm{mM}$ (Table 4, 5 and 6). In agreement with previous studies, it was reported that SA had a greater effect on root growth and root biomass of sorghum and maize under slat stress (El-Katony et al., 2019 and Rajabi et al., 2019). It was also reported that onion bulb diameter statistically reduced and increased under the effect of salt stress and SA, respectively (Pradhan et al., 2016 and StaBaba et al., 2010). Green onion yield (t. ha-1) responses positively to the effect of short-term $\mathrm{SA}$ treatment under $\mathrm{NaCl}$ stress, the lowest yield was recorded when plants were treated with $40 \mathrm{mM} \mathrm{NaCl}$ (Table 7). Statistically, no significant difference was found in the yield of plants treated with SA 0.5 and $1 \mathrm{mM}$ under the effect of 20 and $40 \mathrm{mM} \mathrm{NaCl}$, respectively (Table 7). Many studies examined the response of plant to SA under salt stress (Pradhan et al., 2016; Singh and Roy, 2016 and Wani et al., 2017). Different plant species at different growth stages influenced differently to abiotic and biotic stress under the effect of SA application (Dingre et al., 2016; El-Katony et al., 2019; Mohammadi et al., 2019 and Singh and Roy, 2016). In addition to the defense mechanism against pathogen, SA play a big role to enhance antioxidant system in the plant, and also regulate cell growth and enlargement (Bhasker et al.,2020; Li et al., 2014 and Vanacker et al., 2001). It may suggest that the short- term effect of $\mathrm{NaCl}$ in the field was alleviated by SA application in the early stage of growth and development of green onion (cv. Local red).

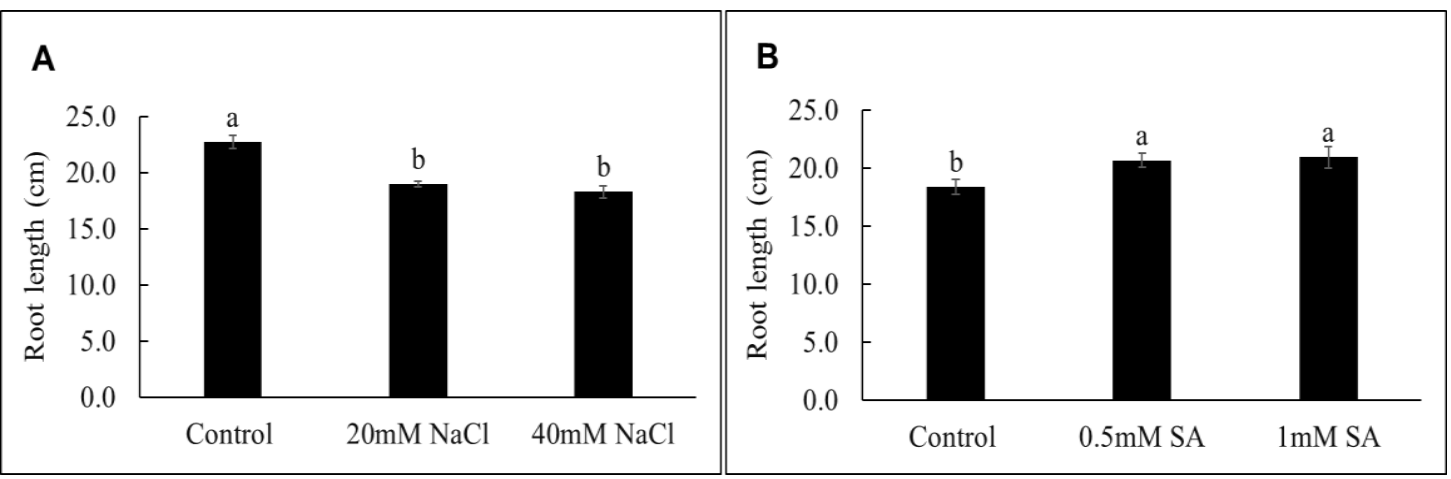

Figure (4): Root length of green onion under the effect of $\mathrm{NaCl}$ and SA. (A)Main effect of $\mathrm{NaCl}$. (B) Main effect of SA on root length $(\mathrm{cm})$ of green onion at the age of 100 DAT. Values with different letters indicate significant difference at $P$ $<0.05$ according to Duncan multiple range test, $n=3$, error bars represent \pm SE. 
Table (4): The interaction effect of $\mathrm{NaCl}$ and $\mathrm{SA}$ on root length $(\mathrm{cm})$ of green onion at the age of 100 DAT.

\begin{tabular}{|c|c|c|c|}
\hline $\mathrm{SA} \mathrm{NaCl}$ & Control & $20 \mathrm{mM} \mathrm{NaCl}$ & $40 \mathrm{mM} \mathrm{NaCl}$ \\
\hline Control & $20.667 \pm 0.36 \mathrm{c}$ & $18.083 \pm 0.22 \mathrm{e}$ & $16.300 \pm 0.29 \mathrm{f}$ \\
\hline $0.5 \mathrm{mM}$ SA & $22.900 \pm 0.37 \mathrm{~b}$ & $19.250 \pm 0.14 \mathrm{~d}$ & $19.750 \pm 0.38 \mathrm{~d}$ \\
\hline $1 \mathrm{mM} \mathrm{SA}$ & $24.458 \pm 0.44 \mathrm{a}$ & $19.500 \pm 0.14 \mathrm{~d}$ & $18.783 \pm 0.24 \mathrm{de}$ \\
\hline
\end{tabular}

Values with different letters indicate significant difference at $\mathrm{P}<0.05$ according to Duncan multiple range test, $\mathrm{n}=3, \pm$ standard error (SE).

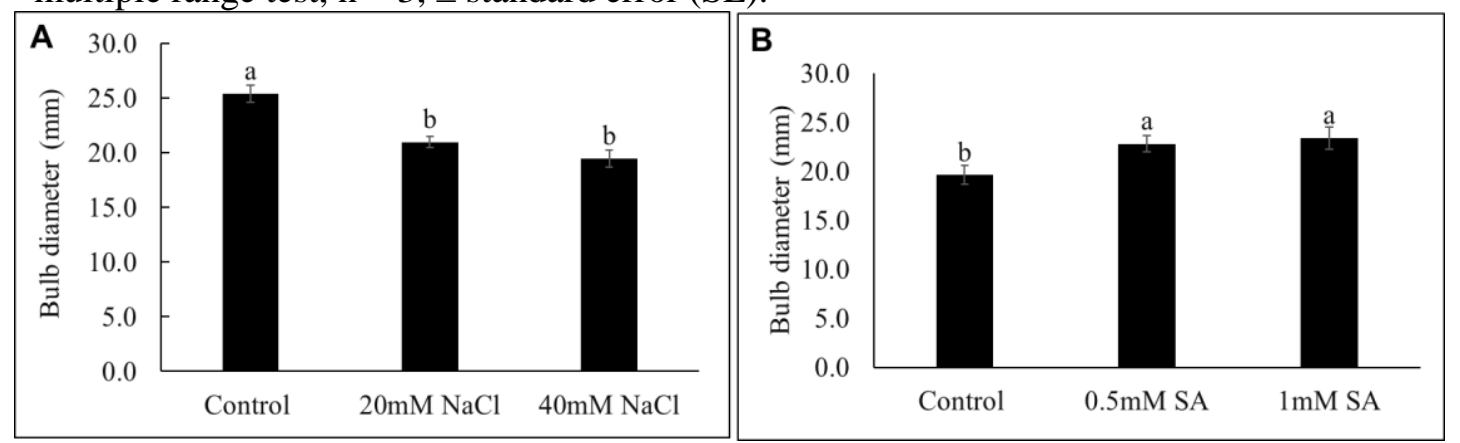

Figure (5): Bulb diameter of green onion under the effect of $\mathrm{NaCl}$ and SA. (A)Main effect of $\mathrm{NaCl}$. (B) Main effect of SA on bulb diameter $(\mathrm{cm})$ of green onion at the age of 100 DAT. Values with different letters indicate significant difference at $\mathrm{P}<0.05$ according to Duncan multiple range test, $\mathrm{n}=3$, error bars represent $\pm \mathrm{SE}$.

Table (5): The interaction effect of $\mathrm{NaCl}$ and $\mathrm{SA}$ bulb diameter $(\mathrm{cm})$ of green onion at the age of 100 DAT.

\begin{tabular}{|c|c|c|c|}
\hline $\mathrm{SA} N \mathrm{NaCl}$ & Control & $20 \mathrm{mM} \mathrm{NaCl}$ & $40 \mathrm{mM} \mathrm{NaCl}$ \\
\hline Control & $22.897 \pm 0.88 \mathrm{c}$ & $19.143 \pm 0.42 \mathrm{~d}$ & $16.779 \pm 0.61 \mathrm{e}$ \\
\hline $0.5 \mathrm{mM} \mathrm{SA}$ & $25.507 \pm 0.57 \mathrm{~b}$ & $22.199 \pm 0.44 \mathrm{c}$ & $20.752 \pm 1.38 \mathrm{~cd}$ \\
\hline $1 \mathrm{mM}$ SA & $27.783 \pm 0.21 \mathrm{a}$ & $21.573 \pm 0.15 \mathrm{c}$ & $20.865 \pm 0.48 \mathrm{~cd}$ \\
\hline
\end{tabular}

Values with different letters indicate significant difference at $\mathrm{P}<0.05$ according to Duncan multiple range test, $\mathrm{n}=3, \pm$ standard error (SE).

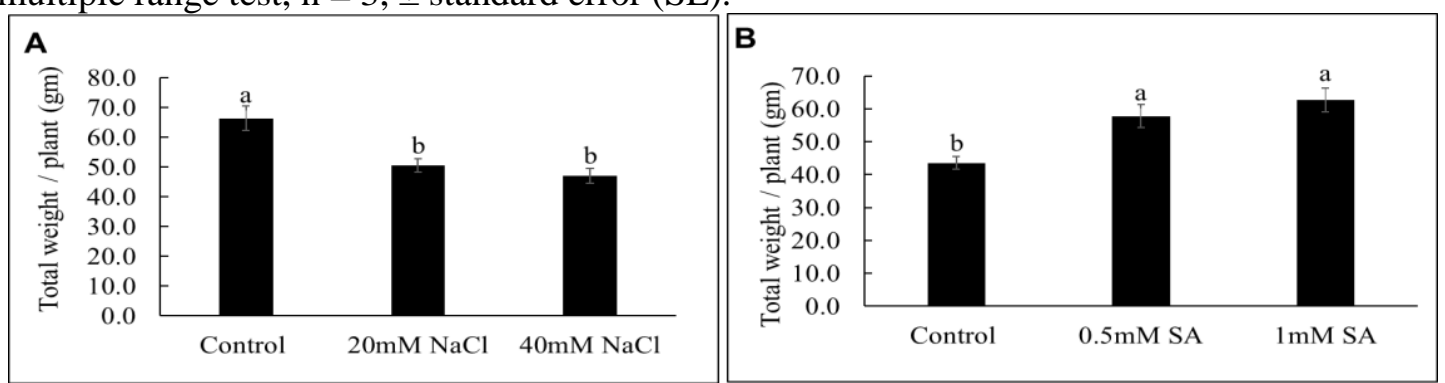

Figure (6): Total weight per plant (gm) of green onion under the effect of $\mathrm{NaCl}$ and SA. (A)Main effect of $\mathrm{NaCl}$. (B) Main effect of SA on the total weight (gm /plant) (root, bulb and green leaves) of green onion at the age of 100 DAT. Values with different letters indicate significant difference at $\mathrm{P}<0.05$ according to Duncan multiple range test, $n=3$, error bars represent $\pm S E$. 
Table (6): The interaction effect of $\mathrm{NaCl}$ and $\mathrm{SA}$ on total weight per plant (gm) of green onion at the age of 100 DAT.

\begin{tabular}{|c|c|c|c|}
\hline $\mathrm{SA} \mathrm{NaCl}$ & Control & $20 \mathrm{mM} \mathrm{NaCl}$ & $40 \mathrm{mM} \mathrm{NaCl}$ \\
\hline Control & $50.583 \pm 0.93 \mathrm{e}$ & $42.250 \pm 0.87 \mathrm{f}$ & $37.700 \pm 0.98 \mathrm{~g}$ \\
\hline $0.5 \mathrm{mM} \mathrm{SA}$ & $71.917 \pm 0.93 \mathrm{~b}$ & $51.917 \pm 0.98 \mathrm{de}$ & $49.667 \pm 1.45 \mathrm{e}$ \\
\hline $1 \mathrm{mM} \mathrm{SA}$ & $76.667 \pm 0.73 \mathrm{a}$ & $57.333 \pm 1.36 \mathrm{c}$ & $54.017 \pm 1.41 \mathrm{~d}$ \\
\hline
\end{tabular}

Values with different letters indicate significant difference at $\mathrm{P}<0.05$ according to Duncan multiple range test, $\mathrm{n}=3, \pm$ standard error $(\mathrm{SE})$.
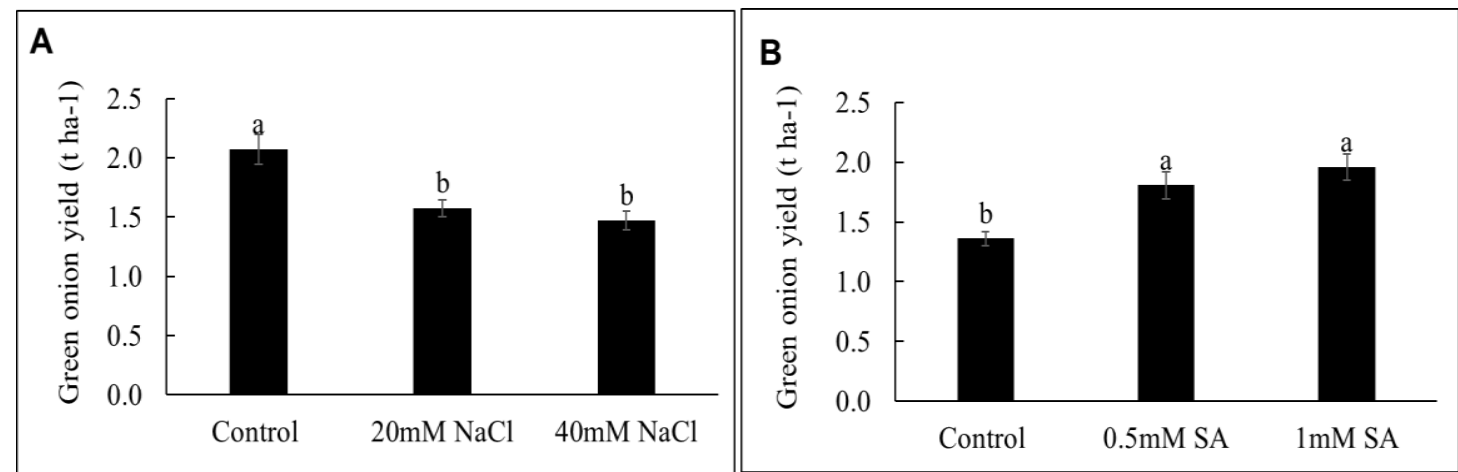

Figure (7): Green onion yield ( $\left.\mathrm{tha}^{-1}\right)$ under the effect of $\mathrm{NaCl}$ and SA. (A)Main effect of $\mathrm{NaCl}$. (B) Main effect of SA on green onion yield (tha-1) at the age of 100 DAT. Values with different letters indicate significant difference at $\mathrm{P}<0.05$ according to Duncan multiple range test, $n=3$, error bars represent \pm SE.

Table (7): The interaction effect of $\mathrm{NaCl}$ and $\mathrm{SA}$ on green onion yield $\left(\mathrm{t} \mathrm{ha}^{-1}\right)$ at the age of 100 DAT.

\begin{tabular}{|c|c|c|c|}
\hline SA NaCl & Control & $20 \mathrm{mM} \mathrm{NaCl}$ & $40 \mathrm{mM} \mathrm{NaCl}$ \\
\hline Control & $1.581 \pm 0.03 \mathrm{e}$ & $1.3203 \pm 0.03 \mathrm{f}$ & $1.1781 \pm 0.03 \mathrm{~g}$ \\
\hline $0.5 \mathrm{mM} \mathrm{SA}$ & $2.247 \pm 0.03 \mathrm{~b}$ & $1.622 \pm 0.03 \mathrm{de}$ & $1.552 \pm 0.04 \mathrm{e}$ \\
\hline $1 \mathrm{mM} \mathrm{SA}$ & $2.396 \pm 0.02 \mathrm{a}$ & $1.792 \pm 0.04 \mathrm{c}$ & $1.688 \pm 0.04 \mathrm{~d}$ \\
\hline
\end{tabular}

Values with different letters indicate significant difference at $\mathrm{P}<0.05$ according to Duncan multiple range test, $\mathrm{n}=3, \pm$ standard error (SE).

In conclusion, onion is one of the most important commercial vegetable crops grown in Iraq. Green onion is heavily consumed as salad or cocked. The yield and planting area of green onion and other economic crops in Iraq, specifically, is reduced because of different reasons including poor irrigation practice, drainage infrastructure and water quality, which cause soil salinization (Qureshi and Al-Falahi, 2015). Salt stress adversely affects plant growth and development at different stages, generally. Various studies were conducted over decades to mitigate the negative response of plant to salt stress and other causes of slat accumulation on the soil surface, including, drought, water quality etc. Attempts were made using various chemical compounds and / or plant regulator to alleviate the adverse effect of salt stress on plant. SA partially neglected the effect of slat stress at the early stage of green onion growth and development. It is suggested firstly, improve the agricultural practices including facilitate drainage and use clean water for crop irrigation. Secondly, introduce commercial 
version of SA to agricultural market. However, further studies are required to examine the effect of SA at different stages of onion growth and development (germination, vegetative and seed production) under abiotic stress.

\section{Acknowledgment}

The research was financially supported by Qudra 2, Hungarian Interchurch Aid (HIA), Erbil, Iraq.

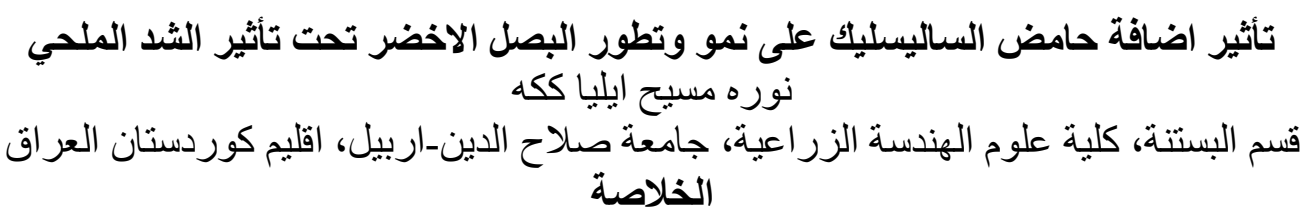

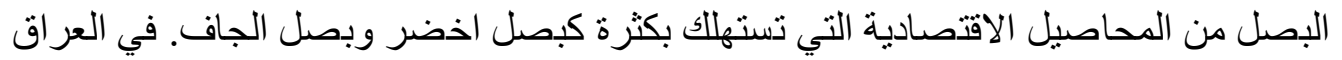

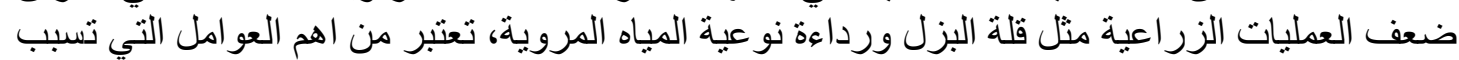

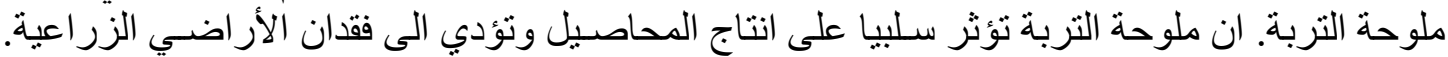

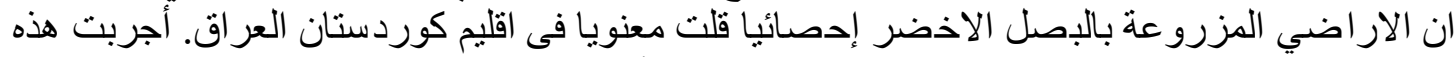

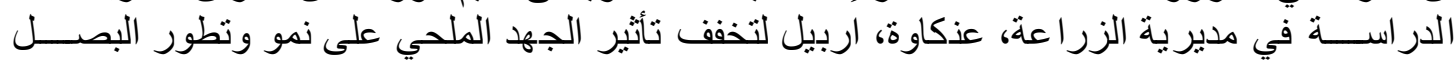

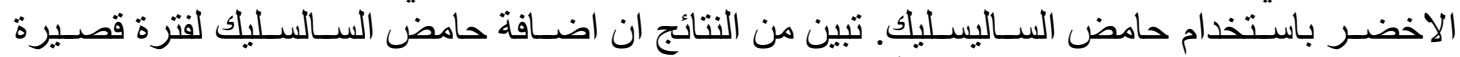

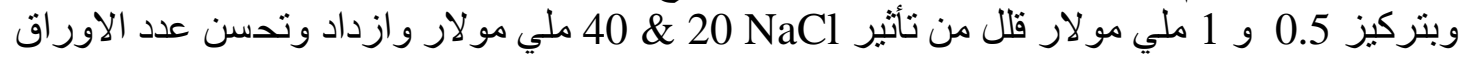

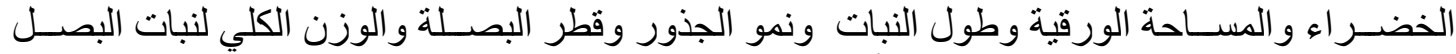

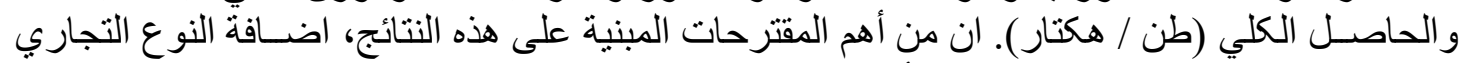

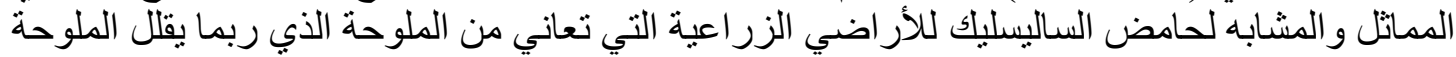

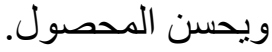
الكلمات المفتاحية: الثد الملحي، حامض الساليسليك، محصول البصل الاخضر

\section{REFERENCES}

Anonymous. (2019). Horticulture Statistical Data Area, Production, Productivity. Ministry of agriculture and water resources kurdistan.

Anonymous. (2021). Monthly weather foreczast and climate Erbil, Iraq. Weather Atlas.

Ashraf, M., Akram, N. A., Arteca, R. N., \& Foolad, M. R. (2010). The physiological, biochemical and molecular roles of brassinosteroids and salicylic acid in plant processes and salt tolerance. Critical Reviews in Plant Sciences, 29(3), 162-190.

Bhasker, P., Gupta, P. K., \& Sharma, H. P. (2020). Role of salicylic acid on growth, yield, quality and disease pest reaction of onion (Allium Cepa L.) CV. Agrifound Light Red. SAARC Journal of Agriculture, 18(1), 39-49.

Córcoles, J. I., Domínguez, A., Moreno, M. A., Ortega, J. F., \& De Juan, J. A. (2015). A non-destructive method for estimating onion leaf area. Irish Journal of Agricultural and Food Research, 54(1), 17-30.

da Silva, J. E., Paiva, E. P. D., Leite, M. D. S., Torres, S. B., Souza, M. L. D., \& Guirra, K. S. (2019). Salicylic acid in the physiological priming of onion seeds subjected to water and salt stresses. Revista Brasileira de Engenharia Agrícola e Ambiental, 23(12), 919-924. 
Dingre, S. K., Pawar, D. D., Kale, K. D., \& Kadam, M. M. (2016). Onion seed productivity, nutrient use, and quality response to drip fertigation in semiarid India. Journal of Plant Nutrition, 39(10), 1391-1403.

Duan, L., Liu, H., Li, X., Xiao, J. and Wang, S., (2014). Multiple phytohormones and phytoalexins are involved in disease resistance to Magnaporthe oryzae invaded from roots in rice. Physiologia plantarum, 152(3), 486500.

El-Katony, T. M., El-Bastawisy, Z. M., \& El-Ghareeb, S. S. (2019). Timing of salicylic acid application affects the response of maize (Zea mays L.) hybrids to salinity stress. Heliyon, 5(4), 1-30.

Herrera-Vásquez, A., Salinas, P., \& Holuigue, L. (2015). Salicylic acid and reactive oxygen species interplay in the transcriptional control of defense genes expression. Frontiers in plant science, 6, (171), 1-9.

Jawad Kadhim, H. (2020). Spatial Relationships of Soil Salinity in Iraq and Its Impact Agricultural Production. AL-Mostansiriyah journal for arab and international studies, 72 (17), 243-259.

Kamran, M., Parveen, A., Ahmar, S., Malik, Z., Hussain, S., Chattha, M. S., Saleem, M.H., Adil, M., Heidari, P. \& Chen, J. T. (2020). An overview of hazardous impacts of soil salinity in crops, tolerance mechanisms, and amelioration through selenium supplementation. International journal of molecular sciences, 21(1), 1-27.

Lastiri-Hernández, M. A., Álvarez-Bernal, D., Conde Barajas, E., \& Miranda, J. G. G. (2021). Biosaline agriculture: an agronomic proposal for onion (Allium cepa L.) production. International Journal of Phytoremediation, 1-9.

Lefevere, H., Bauters, L., \& Gheysen, G. (2020). Salicylic acid biosynthesis in plants. Frontiers in plant science, 11, (338), 1-7.

Li, T., Hu, Y., Du, X., Tang, H., Shen, C., \& Wu, J. (2014). Salicylic acid alleviates the adverse effects of salt stress in Torreya grandis cv. Merrillii seedlings by activating photosynthesis and enhancing antioxidant systems. PLOS one, 9(10), 1-9.

Mohamed, A. A., \& Aly, A. A. (2008). Alternations of some secondary metabolites and enzymes activity by using exogenous antioxidant compound in onion plants grown under seawater salt stress. AmericanEurasian Journal of Scientific Research, 3(2), 139-146.

Mohammadi, M., Chaichi, M. R., \& Safikhani, S. (2019). Salicylic acid application alleviates the salt stress effects in Wheat. International Journal of Development Research, 9 (1), 24976-24981

Plabon, A. R., Hoque, M. E., Vabna, F. A., \& Khatun, F. (2021). In Vitro Regeneration of Onion (Allium cepa L.) Genotypes under Salt Stress Condition. Asian Research Journal of Agriculture, 14(1), 34-43.

Pradhan, M., Tripathy, P., Mandal, P., Sahoo, B. B., Pradhan, R., Mishra, S. P., \& Mishra, H. N. (2016). Effect of salicylic acid on growth and bulb yield of onion (Allium cepa L.). International Journal of Bio-resource and Stress 
Qureshi Management, 7(4), 960-963., A. S., \& Al-Falahi, A. A. (2015). Extent, characterization and causes of soil salinity in central and southern Iraq and possible reclamation strategies. Intternational Journal of Engineering Research and Applications, 5(1), 84-94.

Rajabi Dehnavi, A., Zahedi, M., Razmjoo, J., \& Eshghizadeh, H. (2019). Effect of exogenous application of salicylic acid on salt-stressed sorghum growth and nutrient contents. Journal of Plant Nutrition, 42(11-12), 1333-1349.

Singh, A. (2019). An overview of drainage and salinization problems of irrigated lands. Irrigation and Drainage, 68(3), 551-558.

Singh, D., \& Roy, B. K. (2016). Salt stress affects mitotic activity and modulates antioxidant systems in onion roots. Brazilian Journal of Botany, 39(1), 67-76.

Sta-Baba, R., Hachicha, M., Mansour, M., Nahdi, H., \& Kheder, M. B. (2010). Response of onion to salinity. African Journal of Plant Science and Biotechnology, 4, (2), 7-12.

Vanacker, H., Lu, H., Rate, D. N., \& Greenberg, J. T. (2001). A role for salicylic acid and NPR1 in regulating cell growth in Arabidopsis. The Plant Journal, 28(2), 209-216.

Wani, A. B., Chadar, H., Wani, A. H., Singh, S., \& Upadhyay, N. (2017). Salicylic acid to decrease plant stress. Environmental Chemistry Letters, 15(1), 101-123.

Wijoyo, R. B., Sulistyaningsih, E., \& Wibowo, A. (2020). Growth, Yield and Resistance Responses of Three Cultivars on True Seed Shallots to Twisted Disease with Salicylic Acid Application. Caraka Tani: Journal of Sustainable Agriculture, 35(1), 1-11. 